\title{
Effect of Implementing Transformational Leadership Educational Program on Sense of Responsibility of Nursing Clinical Educators at Faculty of Nursing
}

\author{
Doaa A. Edrees ${ }^{1}$, Seham I. Hamouda ${ }^{2}$,Safaa M. El-Demerdash ${ }^{3}$, Amal H. Abou- \\ Ramadan ${ }^{4}$, \\ ${ }^{1}$ Assistant lecturer, Nursing Service Administration, Faculty of Nursing, Tanta University \\ ${ }^{2,3}$ Professor, Nursing Service Administration, Faculty of Nursing, Tanta University \\ ${ }^{4}$ Assistant professor, Nursing Service Administration, Faculty of Nursing, Tanta University
}

\begin{abstract}
Background: Transformational leadership of nursing clinical educators is preferred for facing challenges that arise from the technological changes of globalization in nursing clinical education. It is also a creative approach which needed to deal with these challenges through enhancement of nursing clinical educators' sense of responsibility. The study was aimed to determine the effect of implementing transformational leadership educational program on sense of responsibility of nursing clinical educators at Faculty of Nursing. Subjects and Method: Design: Quasi-experimental design was used. Setting: Tanta University, Faculty of Nursing. Subject: All (80) nursing clinical educators at the above mentioned setting. Tools: Three tools were used to collect data; I: Nursing clinical educators' knowledge questionnaire about transformational leadership and sense of responsibility. II: Nursing clinical educators' transformational leadership questionnaire. III: Nursing clinical educators' sense of responsibility questionnaire. Results: Majority of nursing clinical educators had poor knowledge level of transformational leadership and sense of responsibility at pre-educational program, while at immediate post and 3 months post educational program, majority of them had good knowledge level. Majority of nursing clinical educators rated themselves as low level of transformational leadership and sense of responsibility at pre-educational program decreased to low percent at immediate post educational program, and at 3 months post educational program. Conclusion: Nursing clinical educators at Tanta University Faculty of Nursing showed low knowledge level of transformational leadership and sense of responsibility. Also, they rated themselves as low level of transformational leadership and sense of responsibility. Nursing clinical educators develop transformational leadership and sense of responsibility after implementation of program. Recommendations: Nursing faculty give more consideration to the crucial role of transformational leadership and sense of responsibility to upgrade the nursing clinical educators.
\end{abstract}

Keywords: Nursing clinical educators, Sense of responsibility, Transformational leadership 


\section{Introduction}

Nursing Clinical Educators (NCEs) are full time clinical teaching staff employed by a university to provide clinical supervision and training for nursing students ${ }^{(1,2)}$. NCEs teach student nurses in clinical class, laboratory, and clinical environments. They play several roles during the clinical learning, including leader role ${ }^{(2-4)}$.

The NCEs' leadership refers to skills exhibited by NCEs to influence nursing students during the clinical training. The most preferred leadership style used is transformational leadership (TL). TL is leadership behaviors that inspire students, result in both NCE and students raising each other up to higher levels of morality, responsibility, motivation, and performance $^{(5-8)}$.

Transformational leadership is characterized by four dimensions, namely idealized influence, intellectual stimulation, individualized consideration, and inspirational motivation ${ }^{(8,9)}$. Idealized influence dimension occurs when transformational NCEs (TNCEs) serve as role model, demonstrate high standards of ethical and moral excellence, and engender admiration, trust, and respect from their students. While intellectual stimulation dimension occurs when TNCEs instill more flexible and creative patterns of thinking by prompting students to think independently, and view problems from different perspectives ${ }^{(9,10)}$.

Whereas, individualized consideration dimension occurs when TNCEs treat students as unique individuals; and consider the student's needs, abilities, and individual differences. Finally, inspirational motivation dimension involves promoting optimism and enthusiasm, treating students as capable and responsible; and recognizing good performance of the students. TNCEs encourages and motivates students to exceed expectations; realize a shared vision of excellence during clinical training; and maximize their personal and collective potential $^{(8,10,11)}$.

The NCEs who use transformational leadership increase nursing students' retention and overall nursing students' outcomes. Also, they emphasize teamwork, ethics, and compassion; devote extra effort; to promote their teaching practices or attitudes; enhance professional learning; improve faculty working environment; and optimize their sense of responsibility ${ }^{(12-14)}$.

Nursing clinical educators' sense of responsibility is a sense of internal obligation and commitment to produce or prevent designated outcomes. It includes four dimensions; responsibility for the clinical teaching, student motivation, having positive relationships with students, 
and student achievement. First, responsibility for clinical teaching clarifies the responsibility of TNCEs as educators through assessing student's learning style, abilities, and needs; supporting the learning objectives through the given information and skills for students ${ }^{(14,15)}$.

Second, responsibility for student motivation involves direct students to plan and organize the clinical training; and give examples of noble work of great personalities. Third, responsibility got having positive relationships with students illustrates TNCE's responsibility to build a positive rapport with students. Finally, responsibility for student achievement involves grading the students; provision of honest, constructive, fair, and positive feedback; documenting student's progress on an ongoing basis; and making students' success top priority ${ }^{(15,16)}$.

\section{Significance of the study}

Nursing clinical educators are challenged to prepare the increasing number of nursing students and seek specialist knowledge to meet the needs of patients, families, and society. Also, changes in the healthcare environment require movement from traditional to more innovative ways of nursing clinical education ${ }^{(5,14,17)}$.

With this dynamic change, the TNCEs with high sense of responsibility become important aspect to put into consideration. So, the need for education and training on transformational leadership for NCEs is critical for the quality improvement of nursing education ${ }^{(8)}$. Accordingly, it was recommended by Edrees (2018) (18) to design an education program for NCEs about transformational leadership to enhance their knowledge and practice. Thus, this study aims to determine effect of implementing transformational leadership educational program for nursing clinical educators on their sense of responsibility.

\section{Aim of the study}

Determine the effect of implementing transformational leadership educational program on sense of responsibility of nursing clinical educators at Faculty of Nursing.

\section{Research hypothesis}

After implementing of the educational program for nursing clinical educators, levels of nursing clinical educators' transformational leadership and their sense of responsibility expected to be improved.

\section{Subjects and Method}

\section{Study design:}

Quasi experimental research design was used to achieve the aim of the present study.

\section{Setting:}

The present study was conducted at Faculty of Nursing, Tanta University. The Faculty consisted of seven academic nursing departments' namely MedicalSurgical Nursing, Maternal and Neonatal Nursing, Pediatric Nursing, Community 
Health and Geriatric Nursing, Nursing Services Administration, Psychiatric and Mental Health Nursing, and Emergency and Critical Care Nursing Department.

\section{Subjects:}

The study subject consisted of all (80) nursing clinical educators who are responsible for students training in clinical areas and working at the above mentioned setting and available at time of data collection.

\section{Tools:}

The data of the study collected using three tools:

\section{Tool I: Nursing clinical educators'}

knowledge questionnaire about

transformational leadership and sense of responsibility.

This tool was developed by the researcher guided Harrison (2011) ${ }^{(8)}$, Lauermann and Karabenick (2013) ${ }^{(15)}$, and recent related literatures. ${ }^{(12,16,17,19-21)}$. It was used to test the nursing clinical educators' knowledge about transformational leadership and sense of responsibility. It included three parts:

Part I: Nursing clinical educators' characteristics as code, age, qualification, academic position, department, years of experience, and previous attending educational program.

Part II: Nursing clinical educators' knowledge test about transformational leadership. It contained 29questions in the form of true \& false (15 questions), multiple choices (5 questions), and cross matching (9 questions). It was classified as follows:-

- Basic concepts of nursing clinical educators' transformational leadership included 11 questions.

- Dimensions of nursing clinical educators' transformational leadership included 11 questions.

- Benefits of using transformational leadership by nursing clinical educators included 10 questions.

Part III: Nursing clinical educators' knowledge test about sense of responsibility. It contained 21 questions in the form of true $\&$ false (15 questions), multiple choices (6 questions), and cross matching (4 questions).

It was classified as follows:-

- Basic concepts and dimensions of nursing clinical educators' sense of responsibility included 9 questions.

- Factors affecting, components, and importance of sense of responsibility included 9 questions.

\section{Scoring system:}

Each question was allotted score of one for correct answer and zero for wrong answer. The total score was determined by adding scores of all questions' answers. The cut point was $60 \%$, and this means the total 
score represented varying levels of nursing clinical educators' knowledge as follows:-

- Good level of knowledge $>75 \%$

- Fair level of knowledge 60 - 75\%

- Poor level of knowledge $<60 \%$

Tool II: Nursing clinical educators' transformational

leadership

\section{questionnaire}

This tool was developed by researcher guided by Harrison (2011) ${ }^{(8)}$, Bryant $(2015)^{(22)}$, and recent related literatures ${ }^{(13,}$ 19, 23-25). It was used to assess nursing clinical educators' transformational leadership from their viewpoint. It included 43 items divided into four dimensions as follows:

- Idealized influence included 14 items.

- Intellectual stimulation included 8 items.

\section{- Individualized}

consideration included 12 items.

- Inspirational motivation included 9 items.

\section{Scoring system:}

Nursing clinical educators' responses was measured on a five points Likert Scale ranging from (1) never to (5) always, Never $=1$, rarely $=2$, sometimes $=3$, often $=$ 4 , and always $=5$. The total score was determined by adding scores of all categories. The cut point was $60 \%$, and this means the total score represented varying levels transformational leadership as follows:

- High transformational leadership level $>75 \%$

- Moderate transformational leadership level $60-75 \%$

- Low transformational leadership level $<60 \%$

Tool III: Nursing clinical educators' sense of responsibility questionnaire

This tool was developed by the researcher guided by Lauermann and Karabenick (2013) ${ }^{(15)}$ and recent related literature ${ }^{(16,}$ 26-31). It was used to assess nursing clinical educators' sense of responsibility from their viewpoint. It included 70 items divided into four dimensions as follow:

- Responsibility for clinical teaching contained 23 items.

- Responsibility for student motivation contained 14 items.

- Responsibility for relationships with students contained 18 items.

- Responsibility for student achievement contained 15 items.

\section{Scoring system:}

Nursing clinical educators' responses were measured on a five points Likert Scale ranging from (1) not at all responsible to (5) completely responsible, Not at all responsible $=1$, less responsible $=2$, somewhat responsible $=3$, responsible $=4$, and completely responsible $=5$. The total 
score was determined by adding scores of all categories. The cut point was $60 \%$, and this means the total score represented varying levels sense of responsibility as follows:

- High sense of responsibility level > $75 \%$

- Moderate sense of responsibility level $60-75 \%$

- Low sense of responsibility level < $60 \%$

\section{Method}

1. An official permission to conduct the study was obtained from Dean of Faculty of Nursing, Tanta University.

\section{Ethical consideration:}

a) Approval of ethical committee at faculty of Nursing was obtained.

b) Informed consent was obtained from nursing clinical educators after explanation of the nature and the aim of the study.

c) Confidentiality and the privacy was taken into consideration regarding to data collection.

3. Tools I, II, and III were developed and designed by the researcher based on review of recent related literatures.

4. The tools were reviewed with supervisors, then submitted to nine experts for testing the content and face validity. They were classified into two professor of Nursing Administration at
Faculty of Nursing, Menoufia University, three assistant professor of Nursing Service Administration, one professor, one assistance professor of Community Health and Geriatric Nursing, one professor of Medical Surgical Nursing, and one professor of Maternal and Neonatal Nursing at Faculty of Nursing, Tanta University.

5. The experts responses were represented in four points rating score ranging from; 4 =strongly relevant, 3 = relevant, $2=$ little relevant, and $1=$ not relevant. Necessary modifications were done, included clarification, omission of certain items and simplifying work related words. The face validity value of tool (I) Nursing clinical educators' transformational leadership questionnaire $=98.37 \%$ and tool (II) Nursing clinical educators' sense of responsibility questionnaire $=99.43 \%$.

6. Pilot study was carried out on a sample $(n=8) \quad 10 \%$ of nursing clinical educators. A pilot study was carried out after the experts' opinion and before starting the actual data collection. The aim of pilot study was to test the sequence, clarity and applicability of the questions.

7. The estimated time needed to complete the questionnaire items were approximately 50 minutes for 
knowledge test tool (I), approximately 20 minutes for nursing clinical educators' transformational leadership questionnaire tool (II), and 35 minutes for nursing clinical educators' sense of responsibility questionnaire tool (III).

8. Reliability of tools were tested using Cronbach Alpha Coefficient test, its value for nursing clinical educators' knowledge questionnaire about transformational leadership and sense of responsibility tool (I) was $\mathbf{0 . 8 3 9}$, for nursing clinical educators' transformational leadership questionnaire tool (II) was $\mathbf{0 . 9 3 5}$, for nursing clinical educators' sense of responsibility questionnaire (III) was 0.922.

9. Data collection: The tools I, II, and III were used before, immediately after, and three months after implementation of the program.

10. Duration of data collection lasted 18 months beginning from July 2019 till December 2020. The assessment phase (pre-test) initiated from July 2019 and followed by period of preparation of the program. Implementation of the program and post-test beginning from July 2020 and finished in September 2020. After 3 months (follow up) phase done from October 2020 to December 2020.
11. The education program for nursing clinical educators was prepared by the researcher based on review of recent relevant different literature.

\section{The educational program}

The educational program was conducted in four phases: Assessment phase, development of the educational program phase, implementation of the educational program phase, and finally evaluation phase.

\section{Phase I: Assessment phase}

- The researcher assessed nursing clinical educators' knowledge about transformational leadership and sense of responsibility through filling part (II) and part (II) of tool (I) before the educational program.

- The researcher assessed levels of nursing clinical educators' transformational leadership and sense of responsibility from their viewpoint by using tool (II) and (III) before implementation of the educational program.

\section{Phase II: Development of the educational program}

The first step in the development of the educational program was the statement of instructional objectives based on assessed need of the sample and literature review.

Aim of the educational program was to determine effect of implementing 
transformational leadership educational program on sense of responsibility of nursing clinical educators at Tanta University.

\section{Objectives of the educational program}

Explain basic concepts of nursing clinical educators' transformational leadership

- Identify dimensions of nursing clinical educators' transformational leadership

- Discuss benefits of nursing clinical educators' transformational leadership.

- Explain basic concepts and dimensions of nursing clinical educators' sense of responsibility.

- Identify factors affecting, components, and importance of sense of responsibility

\section{Selection and organization of content}

The second step after determining the objectives of program was specifically designing the content, and method of teaching. Simple scientific language was used. The content was designed to provide knowledge and practices related to transformational leadership and sense of responsibility. The program contents included five sessions about:

1- Basic concepts of nursing clinical educators' transformational leadership

2- Dimensions of nursing clinical educators' transformational leadership.

3- Benefits of nursing clinical educators' transformational leadership.
4- Basic concepts and dimensions of nursing clinical educators' sense of responsibility.

5- Factors affecting, components, and importance of sense of responsibility.

\section{Teaching - learning strategies}

Selection of teaching method was governed by studying the subject themselves and content of the program. The methods used in teaching of the program were lecture, group discussion, and role play.

\section{Teaching aids}

The teaching aids that were used in the program will be power point (PPT), handout, and example from clinical experience.

Phase III: Implementation of the educational program

- The researcher informed nursing clinical educators about objectives of the educational program and encourage them to participate in the program. The researcher built good relationship with nursing clinical educators to enhance their participation and more involvement in the program.

- Data collection phase: the data was collected from nursing clinical educators by the researcher. Due to the crisis of corona virus and its restrictions 
during the data collection, the researcher conduct the program sessions on-line for 50 nursing clinical educators through Zoom Cloud Meetings Application.

- The tools send to them through WhatsApp Messenger. The researcher divided those nursing clinical educators into ten group. When the restrictions of corona virus decreased, the researcher met the rest (30) of nursing clinical educators in their work place in conference room and nursing clinical educators' room at Faculty of Nursing, Tanta University. The researcher divided them into six groups.

- The program for 80 nursing clinical educators. The program time was 10 hours for each group. One session every day (2hrs every day for 5 days).

\section{Phase IV: Evaluation of the educational}

\section{program}

- The researcher evaluated the program by using the tools (I), (II), and (III) pre, immediately post, and three months after the implementation of the program. The program for nursing clinical educators was evaluated to determine the extent to which nursing clinical educators changed in their practice and knowledge about their transformational leadership and sense of responsibility.
- The levels of nursing clinical educators' knowledge of transformational leadership and sense of responsibility were improved significantly post educational program and at 3 month post educational program than pre- educational program.

- The levels of transformational leadership and sense of responsibility from nursing clinical educators' viewpoint were improved significantly post educational program and at 3 month post educational program than pre-educational program.

\section{Statistical analysis}

Data were analyzed by using IBM SPSS software package version 20.0. Qualitative data were termed by percent and number. Quantitative data were analyzed through mean, range (minimum and maximum), standard deviation. Significance of the results was judged at the $5 \%$ level. The used tests were ANOVA with repeated measures, Friedman test, Post Hoc Test (Dunn's), Cronbach's Alpha test, and Pearson coefficient ${ }^{(32)}$.

\section{Results}

Table (1): Shows distribution of nursing clinical educators' characteristics including the age, marital status, qualification, academic position, years of experience, attendance of previous teaching program as well as departments. It was observed 
that, sixty $(60 \%)$ of nursing clinical educators aged less than 30 years with mean $28.84 \pm 3.23$, more than two third (75\%) of them were married, and more than half $(58.8 \%)$ of them had bachelor degree and worked as a demonstrator. More than half (52.5) of nursing clinical educators not attended previous teaching training program, and $51.3 \%$ of them had less than 5 years of experience with mean years of experience $4.95 \pm 3.60$.

Regarding department, $20 \%$ of nursing clinical educators were from Maternal and Neonatal Nursing, $17.5 \%$ from MedSurgical Nursing, $16.3 \%$ from Nursing Services Administration, $12.5 \%$ from Pediatric Nursing, 12.5\% from Psychiatric and Mental Health Nursing, 11.2\% Community Health \& Geriatric Nursing, and $10 \%$ from Emergency and Critical Care Nursing Department.

Table (2) and figure (1): Represents levels, mean score, and mean percent of nursing clinical educators' transformational leadership knowledge pre, immediate post, and at 3 months post educational program. It was observed that high percent $(97.5 \%)$ of nursing clinical educators had poor level of transformational leadership knowledge at pre educational program, while at immediate post educational program majority $(98.8 \%)$ of them had good level of transformational leadership knowledge and 3 months post educational program majority $(91.3 \%)$ of them had good level of knowledge

Moreover, the table shows there were significant improvement in overall mean score and mean percent of nursing clinical educators' transformational leadership knowledge at $\mathrm{P} \leq 0.05$ immediate post educational program and at 3 month post educational program than pre-educational program. The total mean score of nursing clinical educators' transformational leadership knowledge was $5.94 \pm 4.42$ with low mean percent $(20.47 \%)$ at pre educational program which increased to $28.11 \pm 1.24$ with high mean percent $(96.94 \%)$ at post educational program, and reached to $25.65 \pm 2.72$ with mean percent $(88.45 \%)$ at 3 months post educational program.

Table (3) and figure (2): Represent levels, mean scores, mean percent of nursing clinical educators' knowledge regarding sense of responsibility at pre, immediate post, and 3 months post educational program. It was observed that majority (97.5\%) of nursing clinical educators had poor level of sense of responsibility knowledge at pre-educational program, while at immediate post educational program majority (100\%) of them had good level of sense of responsibility knowledge and 3 months post educational 
program majority $(83.8 \%)$ of them had good level of knowledge.

Moreover, the table shows there were significant improvement in overall mean score and mean percent of nursing clinical educators' knowledge about sense of responsibility at $\mathrm{P} \leq 0.05$ immediate post educational program and at 3 month post educational program than pre educational program. The total mean score of nursing clinical educators' knowledge about sense of responsibility was $3.83 \pm$ 2.82 with low mean percent $(18.21 \%)$ at pre educational program which increased to $19.83 \pm 1.18$ with high mean percent $(94.40 \%)$ at immediate post educational program, and reached to $17.39 \pm 2.16$ with mean percent $(82.80 \%)$ at 3 months post educational program.

Table (4) and figure (3): Illustrates levels, mean score, mean percent of transformational leadership from nursing clinical educators' viewpoint pre, immediate post, and 3 months post program. It was observed that the majority $(86.3 \%)$ of nursing clinical educators rated themselves as low level of transformational leadership at preeducational program decreased to low percent $(2.5 \%)$ immediate post educational program. and reach to $12.5 \%$ at 3 months post educational program.

As shown in the table (4), It was observed that the overall levels of transformational leadership from nursing clinical educators' viewpoint were improved significantly at $P$ $\leq 0.05$ immediate post educational program and at 3 month post educational program than pre-educational program. Also, there were significant improvement in overall mean score and mean percent of nursing clinical educators' transformational leadership at $\mathrm{P} \leq 0.05$ immediate post educational program and at 3 month post educational program than pre-educational program. The total mean score of nursing clinical educators' transformational leadership was $80.0 \pm 12.71$ with low mean percent $(43.02 \%)$ at pre educational program which increased to $111.51 \pm 8.87$ with high mean percent $(79.67$ $\%)$ at immediate post educational program, and reached to $107.3 \pm 8.48$ with mean percent $(74.78 \%)$ at 3 months post educational program.

Table (5) and figure (4): Illustrates levels, mean score, and mean percent sense of responsibility from nursing clinical educators' viewpoint at pre, immediate post, and 3 months post program. The majority $(92.5 \%)$ of nursing clinical educators felt themselves as low level of sense of responsibility at pre-educational program decreased to low percent $(0 \%)$ immediate post educational program. and reach to $1.3 \%$ at 3 months post educational program. 
As shown in the table (5), It was observed that, the overall levels of sense of responsibility from nursing clinical educators' viewpoint were improved significantly at $\mathrm{P} \leq 0.05$ immediate post educational program and at 3 month post educational program than pre-educational program. Also, there were significant improvement in overall mean score and mean percent of nursing clinical educators' sense of responsibility at $\mathrm{P} \leq 0.05$ immediate post educational program and at 3 month post educational program than pre-educational program. The total mean score of nursing clinical educators' sense of responsibility was $132.68 \pm 17.37$ with low mean percent $(44.77 \%)$ at preeducational program which increased to $192.80 \pm 12.18$ with high mean percent $(87.71 \%)$ at immediate post educational program and reached to $185.71 \pm$ 14.45 with mean percent $(82.65 \%)$ at 3 months post educational program.

Table (6): Illustrates correlation between nursing clinical educators' transformational leadership knowledge and their knowledge about sense of responsibility at pre, immediate post, and 3 months post educational program. From the table, there was a statistically significant positive correlation between nursing clinical educators' transformational leadership knowledge and their knowledge about sense of responsibility at pre, immediate post, and 3 months post educational program (at $\mathrm{P} \leq 0.05$ ).

Table (7): Illustrates correlation between nursing clinical educators' transformational leadership knowledge and transformational leadership from their viewpoint at pre, immediate post, and 3 months post educational program. From the table, there was a statistically significant positive correlation between nursing clinical educators' transformational leadership knowledge and transformational leadership from their viewpoint at pre, immediate post, and 3 months post educational program (at $\mathrm{P} \leq 0.05$ ).

Table (8): Illustrates correlation between nursing clinical educators' knowledge about sense of responsibility and sense of responsibility from their viewpoint at pre, immediate post, and 3 months post educational program. From the table, there was a statistically significant positive correlation between nursing clinical educators' knowledge about sense of responsibility and sense of responsibility from their viewpoint at pre, immediate post, and 3 months post educational program (at $\mathrm{P} \leq 0.05$ ).

Table (9): Illustrates correlation between transformational leadership from nursing clinical educators' viewpoint and sense of responsibility from their viewpoint at pre, immediate post, and 3 months post educational program. From the table, there was a statistically significant positive correlation between transformational leadership from nursing clinical educators' viewpoint and sense of responsibility from their viewpoint at pre, immediate post, and 3 months post educational program (at $\mathrm{P} \leq$ $0.05)$. 
Table (1): Distribution of nursing clinical educators' according to their characteristics $(\mathbf{n}=\mathbf{8 0})$

\begin{tabular}{|c|c|c|}
\hline Nursing clinical educators' characteristics & No. & $\%$ \\
\hline \multicolumn{3}{|l|}{ Age (years) } \\
\hline$<30$ & 48 & 60.0 \\
\hline $30-<35$ & 27 & 33.8 \\
\hline$\geq 35$ & 5 & 6.2 \\
\hline Min. - Max. & \multirow{2}{*}{\multicolumn{2}{|c|}{$\begin{array}{c}24.0-38.0 \\
28.84 \pm 3.23\end{array}$}} \\
\hline Mean \pm SD & & \\
\hline \multicolumn{3}{|l|}{ Marital status } \\
\hline Married & 60 & 75.0 \\
\hline Divorced & 1 & 1.2 \\
\hline Single & 19 & 23.8 \\
\hline Widow & 0 & 0.0 \\
\hline \multicolumn{3}{|l|}{ Qualification } \\
\hline Bachelor degree & 47 & 58.8 \\
\hline Master degree & 33 & 41.2 \\
\hline \multicolumn{3}{|l|}{ Academic position } \\
\hline Demonstrator & 47 & 58.8 \\
\hline Assistant lecturer & 33 & 41.2 \\
\hline \multicolumn{3}{|l|}{ Years of experience (years) } \\
\hline$<5$ & 41 & 51.3 \\
\hline $5-<10$ & 26 & 32.5 \\
\hline$\geq 10$ & 13 & 16.2 \\
\hline Min. - Max. & \multirow{2}{*}{\multicolumn{2}{|c|}{$\begin{array}{c}0.0-13.0 \\
4.95 \pm 3.60\end{array}$}} \\
\hline Mean \pm SD & & \\
\hline \multicolumn{3}{|l|}{ Attendance of previous teaching training } \\
\hline Yes & 38 & 47.5 \\
\hline No & 42 & 52.5 \\
\hline \multicolumn{3}{|l|}{ Department } \\
\hline -Med-Surgical Nursing & 14 & 17.5 \\
\hline - Community Health \& Geriatric Nursing & 9 & 11.3 \\
\hline - Pediatric Nursing & 10 & 12.5 \\
\hline - Nursing Services Administration & 13 & 16.2 \\
\hline - Psychiatric and Mental Health Nursing & 10 & 12.5 \\
\hline - Maternal and Neonatal Nursing & 16 & 20.0 \\
\hline - Emergency and Critical Care Nursing & 8 & 10.0 \\
\hline
\end{tabular}


Table (2): Levels, mean score, and mean percent of nursing clinical educators' transformational leadership knowledge pre, immediate post, and at 3 months post educational program $(n=80)$

\begin{tabular}{|c|c|c|c|c|c|c|c|c|}
\hline \multirow{3}{*}{$\begin{array}{c}\text { levels of } \\
\text { Transformational } \\
\text { leadership } \\
\text { Knowledge }\end{array}$} & \multicolumn{6}{|c|}{ Nursing clinical educators $(n=80)$} & \multirow{3}{*}{ Test of sig.(P) } & \multirow{3}{*}{$\begin{array}{l}\mathbf{P}_{1} \\
\mathbf{P 2} \\
\mathbf{P 3}\end{array}$} \\
\hline & \multicolumn{2}{|c|}{ Pre } & \multicolumn{2}{|c|}{$\begin{array}{c}\text { Immediate } \\
\text { Post }\end{array}$} & \multicolumn{2}{|c|}{3 months post } & & \\
\hline & No. & $\%$ & No. & $\%$ & No. & $\%$ & & \\
\hline Poor & 78 & 97.5 & 0 & 0.0 & 0 & 0.0 & \multirow{3}{*}{$\begin{array}{c}\mathrm{Fr}=156.390^{*} \\
\left(<0.001^{*}\right)\end{array}$} & $<0.001^{*}$ \\
\hline Fair & 2 & 2.5 & 1 & 1.3 & 7 & 8.8 & & $<0.001^{*}$ \\
\hline Good & 0 & 0.0 & 79 & 98.8 & 73 & 91.3 & & 0.635 \\
\hline \multicolumn{9}{|l|}{ Total score } \\
\hline Min. - Max. & \multicolumn{2}{|c|}{$0.0-19.0$} & \multicolumn{2}{|c|}{$21.0-29.0$} & \multicolumn{2}{|c|}{$18.0-29.0$} & \multirow{5}{*}{$\begin{array}{c}\mathrm{F}=1735.504^{*} \\
\left(<0.001^{*}\right)\end{array}$} & \multirow{5}{*}{$\begin{array}{l}<0.001^{*} \\
<0.001^{*} \\
<0.001^{*}\end{array}$} \\
\hline Mean \pm SD & \multicolumn{2}{|c|}{$5.94 \pm 4.42$} & \multicolumn{2}{|c|}{$28.11 \pm 1.24$} & \multicolumn{2}{|c|}{$25.65 \pm 2.72$} & & \\
\hline$\%$ score & \multirow{2}{*}{\multicolumn{2}{|c|}{$0.0-65.52$}} & \multirow{2}{*}{\multicolumn{2}{|c|}{$72.41-100.0$}} & \multirow{2}{*}{\multicolumn{2}{|c|}{$62.07-100.0$}} & & \\
\hline Min. - Max. & & & & & & & & \\
\hline Mean \pm SD & \multicolumn{2}{|c|}{$\begin{array}{c}20.47 \pm \\
15.24\end{array}$} & \multicolumn{2}{|c|}{$96.94 \pm 4.28$} & \multicolumn{2}{|c|}{$88.45 \pm 9.38$} & & \\
\hline
\end{tabular}

Fr: Friedman test, Sig. bet. periods was done using Post Hoc Test (Dunn's)

F: F test (ANOVA) with repeated measures, Sig. bet. periods was done using Post Hoc Test (adjusted Bonferroni)

P: $\mathrm{p}$ value for comparison between the studied periods

$\mathbf{P}_{1}$ : p value for comparison between Pre and Post

$\mathbf{P}_{2}$ : $\mathrm{p}$ value for comparison between Pre and 3 month Post

$\mathbf{P}_{3}$ : p value for comparison between Post and 3 month Post

*: Statistically significant at $\mathrm{p} \leq 0.05$ 


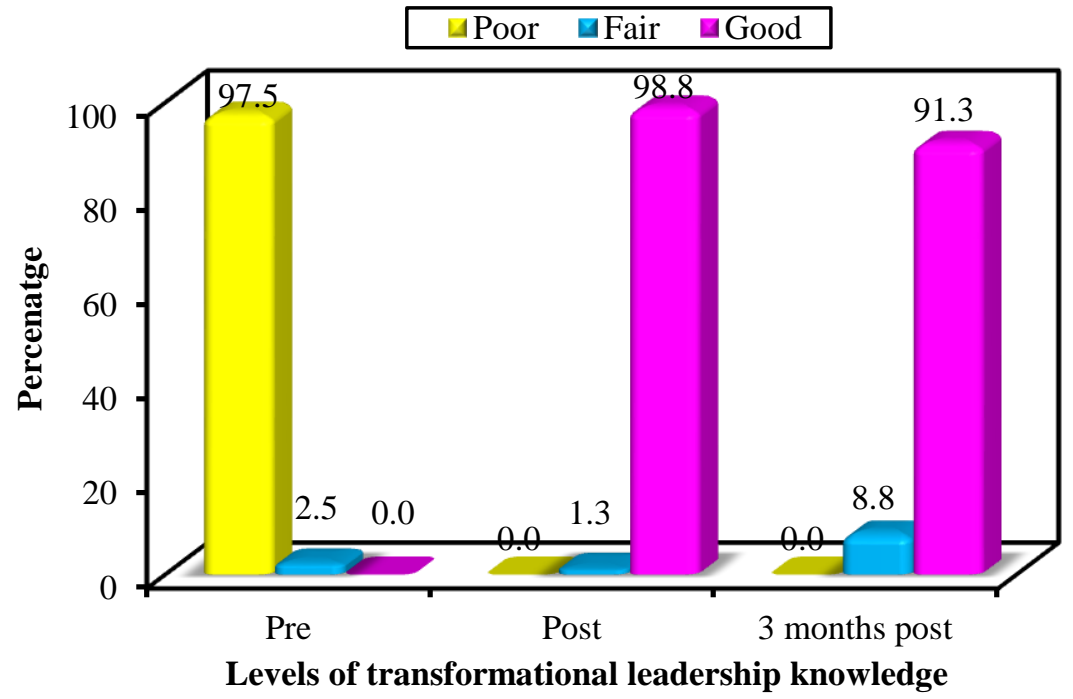

Figure (1): Levels of nursing clinical educators' transformational leadership knowledge pre, immediate post, and at 3 months post educational program $(n=80)$

Table (3): Levels, mean scores, mean percent of nursing clinical educators' knowledge regarding sense of responsibility at pre, immediate post, and 3 months post educational program $(n=80)$

\begin{tabular}{|c|c|c|c|c|c|c|c|c|}
\hline \multirow{3}{*}{\begin{tabular}{|} 
Knowledge levels of \\
sense of \\
responsibility
\end{tabular}} & \multicolumn{6}{|c|}{ Nursing clinical educators $(n=80)$} & \multirow{3}{*}{ Test of sig.(P) } & \multirow{3}{*}{$\begin{array}{l}\text { P1 } \\
\text { P2 } \\
\text { P3 }\end{array}$} \\
\hline & \multicolumn{2}{|c|}{ Pre } & \multicolumn{2}{|c|}{$\begin{array}{c}\text { Immediate } \\
\text { post }\end{array}$} & \multicolumn{2}{|c|}{$\begin{array}{c}3 \text { months post } \\
\text { educational } \\
\text { program }\end{array}$} & & \\
\hline & No. & $\%$ & No. & $\%$ & No. & $\%$ & & \\
\hline Poor & 78 & 97.5 & 0 & 0.0 & 0 & 0.0 & & $<0.001^{*}$ \\
\hline Fair & 2 & 2.5 & 0 & 0.0 & 13 & 16.3 & $\mathrm{Fr}=153.115^{*}$ & $<0.001^{*}$ \\
\hline Good & 0 & 0.0 & 80 & 100.0 & 67 & 83.8 & $\left(<0.001^{*}\right)$ & 0.304 \\
\hline Total score & \multirow{2}{*}{\multicolumn{2}{|c|}{ (15 }} & \multirow{2}{*}{\multicolumn{2}{|c|}{$16.0-21.0$}} & \multirow{2}{*}{\multicolumn{2}{|c|}{$13.0-21.0$}} & \multirow{6}{*}{$\begin{array}{c}\mathrm{F}=2330.112^{*} \\
\left(<0.001^{*}\right)\end{array}$} & \multirow{6}{*}{$\begin{array}{l}<0.001 * \\
<0.001 * \\
<0.001\end{array}$} \\
\hline Min. - Max. & & & & & & & & \\
\hline Mean \pm SD & 3.83 & 2.82 & 19.83 & \pm 1.18 & 17.39 & \pm 2.16 & & \\
\hline$\%$ score & \multirow{2}{*}{\multicolumn{2}{|c|}{$0.0-71.43$}} & \multirow{2}{*}{\multicolumn{2}{|c|}{$76.19-100.0$}} & \multirow{2}{*}{\multicolumn{2}{|c|}{$61.90-100.0$}} & & \\
\hline Min. - Max. & & & & & & & & \\
\hline Mean \pm SD & \multicolumn{2}{|c|}{$18.21 \pm 13.44$} & \multicolumn{2}{|c|}{$94.40 \pm 5.61$} & \multicolumn{2}{|c|}{$82.80 \pm 10.26$} & & \\
\hline
\end{tabular}




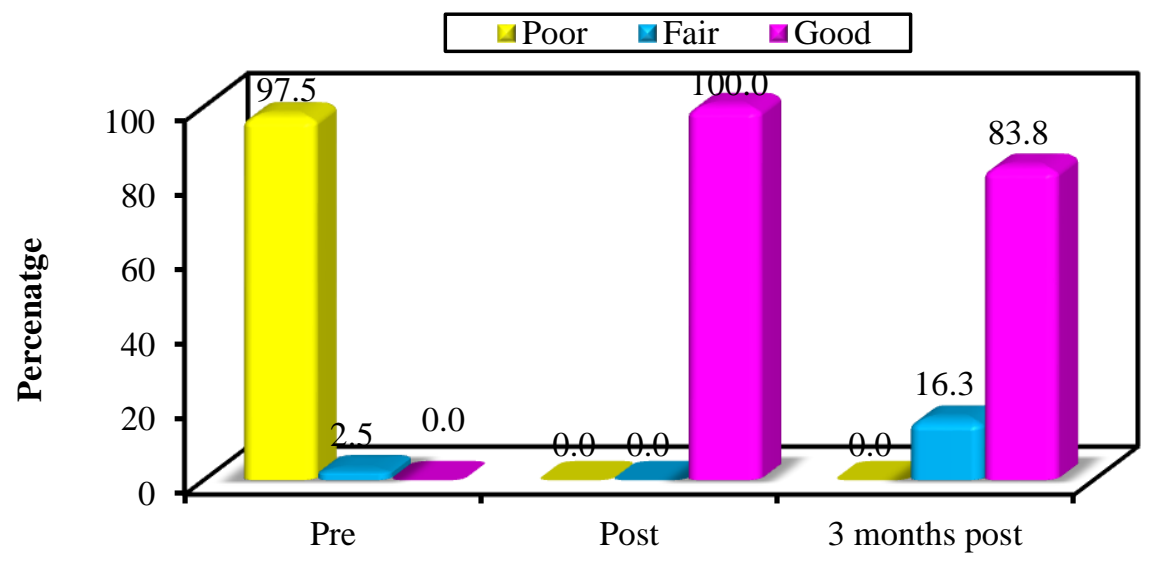

Knowledge levels of sense of responsibility

Figure (2): Levels of nursing clinical educators' knowledge regarding sense of responsibility pre, immediate post, and at 3 months post educational $\operatorname{program}(\mathbf{n}=\mathbf{8 0})$

Table (4): Levels, mean score, mean percent of transformational leadership from nursing clinical educators' viewpoint pre, immediate post, and 3 months post program $(n=80)$

\begin{tabular}{|c|c|c|c|c|c|c|c|c|}
\hline \multirow{3}{*}{$\begin{array}{c}\text { Transformational } \\
\text { leadership from nursing } \\
\text { clinical educators' } \\
\text { viewpoint }\end{array}$} & \multicolumn{6}{|c|}{ Nursing clinical educators $(\mathrm{n}=\mathbf{8 0})$} & \multirow{3}{*}{ Test of sig.(P) } & \multirow{3}{*}{$\begin{array}{l}\mathbf{P}_{1} \\
\mathbf{P 2} \\
\mathbf{P 3}\end{array}$} \\
\hline & \multicolumn{2}{|c|}{ Pre } & \multicolumn{2}{|c|}{$\begin{array}{c}\text { immediate } \\
\text { Post }\end{array}$} & \multicolumn{2}{|c|}{$\begin{array}{l}3 \text { months } \\
\text { post }\end{array}$} & & \\
\hline & $\mathbf{N}$ & $\%$ & $\mathbf{N}$ & $\%$ & $\mathbf{N}$ & $\%$ & & \\
\hline Low & 69 & 86.3 & 2 & 2.5 & 10 & 12.5 & & $<0.001^{*}$ \\
\hline Moderate & 11 & 13.8 & 25 & 31.3 & 24 & 30.0 & $\begin{array}{c}\mathrm{Fr}=139.328^{*} \\
\left(<0.001^{*}\right)\end{array}$ & $<0.001^{*}$ \\
\hline High & 0 & 0.0 & 53 & 66.3 & 46 & 57.5 & & 0.133 \\
\hline \multicolumn{9}{|l|}{ Total score } \\
\hline Min. - Max. & \multicolumn{2}{|c|}{$\begin{array}{l}59.00- \\
105.00\end{array}$} & \multicolumn{2}{|c|}{$93.00-129.0$} & \multicolumn{2}{|c|}{$\begin{array}{c}92.00- \\
122.00\end{array}$} & \multirow{5}{*}{$\begin{array}{c}\mathrm{F}=\mathbf{9 2 6 . 7 1 6 ^ { * }} \\
\left(<0.001^{*}\right)\end{array}$} & \multirow{5}{*}{$\begin{array}{c}<0.001^{*}<0.001^{*}< \\
0.001^{*}\end{array}$} \\
\hline Mean \pm SD & 12.71 & 80.0 & $8.87 \pm$ & 11.51 & $8.48 \pm$ & 07.31 & & \\
\hline$\%$ score & & & & & & & & \\
\hline Min. - Max. & \multicolumn{2}{|c|}{$18.60-72.09$} & \multicolumn{2}{|c|}{$58.14-100.00$} & \multicolumn{2}{|c|}{$56.98-91.86$} & & \\
\hline Mean \pm SD & \multicolumn{2}{|c|}{$14.78 \pm 43.02$} & \multicolumn{2}{|c|}{$10.32 \pm 79.67$} & \multicolumn{2}{|c|}{$9.86 \pm 74.78$} & & \\
\hline
\end{tabular}




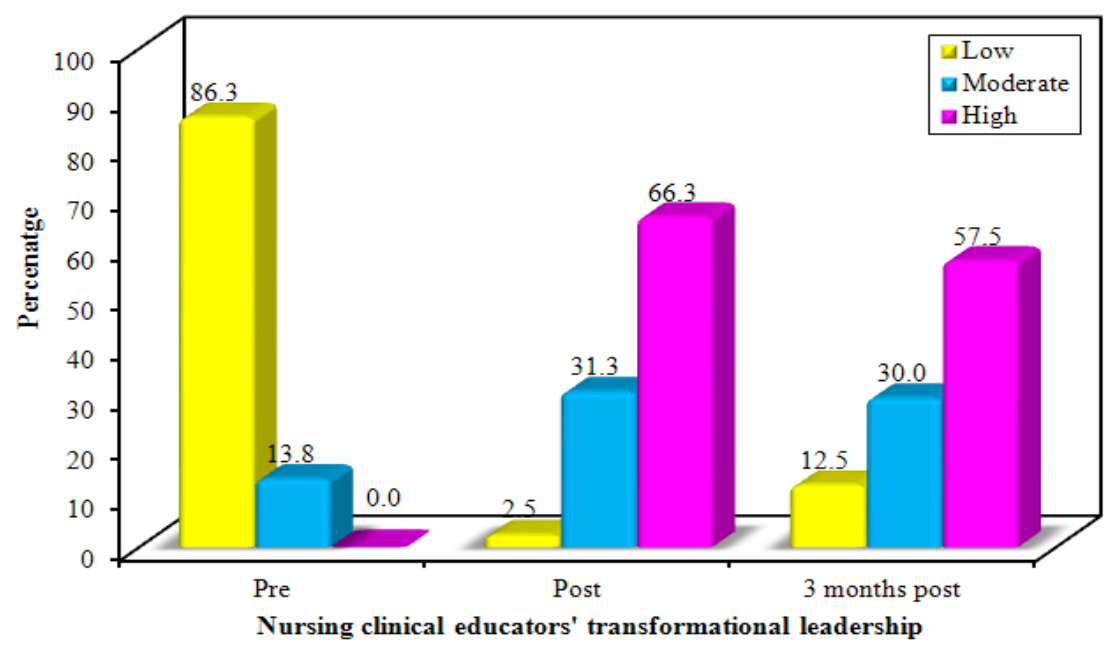

Figure (3): Levels of transformational leadership from nursing clinical educators' viewpoint pre, immediate post, and 3 months post program $(n=80)$

Table (5): Levels, mean score, and mean percent of sense of responsibility from nursing clinical educators' viewpoint at pre, immediate post, and 3 months post program $(\mathbf{n}=\mathbf{8 0})$

\begin{tabular}{|c|c|c|c|c|c|c|c|c|}
\hline \multirow{3}{*}{\begin{tabular}{|c} 
Sense of \\
responsibility \\
from nursing \\
clinical \\
educators' \\
viewpoint
\end{tabular}} & \multicolumn{6}{|c|}{ Nursing clinical educators $(\mathrm{N}=\mathbf{8 0})$} & \multirow{3}{*}{$\begin{array}{l}\text { Test of } \\
\text { sig.(P) }\end{array}$} & \multirow{3}{*}{$\begin{array}{l}\mathbf{P}_{1} \\
\mathbf{P} 2 \\
\mathbf{P 3}\end{array}$} \\
\hline & \multicolumn{2}{|c|}{ Pre } & \multicolumn{2}{|c|}{ Immediate post } & \multicolumn{2}{|c|}{3 months post } & & \\
\hline & $\mathbf{N}$ & $\%$ & $\mathbf{N}$ & $\%$ & $\mathbf{N}$ & $\%$ & & \\
\hline Low & 74 & 92.5 & 0 & 0.0 & 1 & 1.3 & & $<0.001^{*}$ \\
\hline Moderate & 6 & 7.5 & 10 & 12.5 & 20 & 25.0 & $\begin{array}{c}\mathrm{Fr}=152.327^{*} \\
\left(<0.001^{*}\right)\end{array}$ & $<0.001^{*}$ \\
\hline High & 0 & 0.0 & 70 & 87.5 & 59 & 73.8 & & 0.323 \\
\hline \multicolumn{9}{|l|}{ Total score } \\
\hline Min. - Max. & \multicolumn{2}{|c|}{$100.0-166.0$} & \multicolumn{2}{|c|}{$164.0-209.0$} & \multicolumn{2}{|c|}{$151.0-205.0$} & & \\
\hline Mean \pm SD & \multicolumn{2}{|c|}{$132.68 \pm 17.37$} & \multicolumn{2}{|c|}{$192.80 \pm 12.18$} & \multicolumn{2}{|c|}{$185.71 \pm 14.45$} & $F=1906.60^{*}$ & $<0.001^{*}$ \\
\hline$\%$ score & \multirow{2}{*}{\multicolumn{2}{|c|}{$21.43-68.57$}} & \multirow{2}{*}{\multicolumn{2}{|c|}{$67.14-99.29$}} & \multirow{2}{*}{\multicolumn{2}{|c|}{$57.86-96.43$}} & $\left(<0.001{ }^{*}\right)$ & $<0.001^{*}$ \\
\hline Min. - Max. & & & & & & & & $<0.001^{*}$ \\
\hline Mean \pm SD & \multicolumn{2}{|c|}{$44.77 \pm 12.41$} & \multicolumn{2}{|c|}{$87.71 \pm 8.70$} & \multicolumn{2}{|c|}{$82.65 \pm 10.32$} & & \\
\hline
\end{tabular}

Fr: Friedman test, Sig. bet. periods was done using Post Hoc Test (Dunn's)

F: F test (ANOVA) with repeated measures, Sig. bet. periods was done using Post Hoc Test (adjusted Bonferroni) 


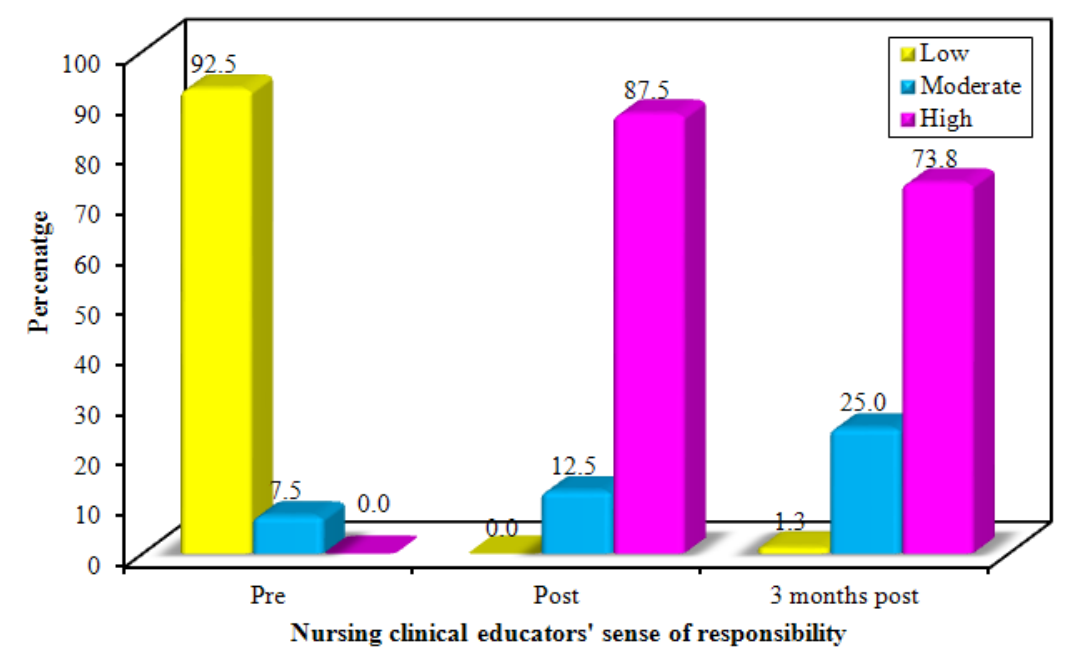

Figure (4): Levels of sense of responsibility from nursing clinical educators' viewpoint at pre, immediate post, and 3 months post program $(n=80)$

Table (6): Correlation between nursing clinical educators' knowledge about transformational leadership and their knowledge about sense of responsibility at pre, immediate post, and 3 months post program $(n=80)$

\begin{tabular}{||l|c|c|c|c|c|c||}
\hline \multirow{3}{*}{} & \multicolumn{5}{|c|}{ Transformational leadership knowledge } \\
\cline { 2 - 7 } & \multicolumn{2}{|c|}{ Pre-program } & \multicolumn{2}{|c|}{$\begin{array}{c}\text { Immediate post - } \\
\text { program }\end{array}$} & \multicolumn{2}{c|}{$\begin{array}{c}\text { 3 months } \\
\text { post -program }\end{array}$} \\
\cline { 2 - 7 } & $\mathbf{r}$ & $\mathbf{P}$ & $\mathbf{r}$ & $\mathbf{P}$ & $\mathbf{r}$ & $\mathbf{P}$ \\
\hline $\begin{array}{l}\text { Knowledge about sense of } \\
\text { responsibility }\end{array}$ & $0.739^{*}$ & $<0.001^{*}$ & $0.282^{*}$ & $0.011^{*}$ & $0.427^{*}$ & $<0.001^{*}$ \\
\hline
\end{tabular}

r: Pearson coefficient

*: Statistically significant at $\mathrm{p} \leq 0.05$ 
Table (7): Correlation between nursing clinical educators' transformational leadership knowledge and transformational leadership from their viewpoint at pre, immediate post, and 3 months post educational program $(n=80)$

\begin{tabular}{||l|c|c|c|c|c|c||}
\hline \multirow{2}{*}{} & \multicolumn{6}{|c|}{ Transformational leadership knowledge } \\
\cline { 2 - 7 } & \multicolumn{2}{|c|}{ Pre-program } & $\begin{array}{c}\text { Immediate post - } \\
\text { program }\end{array}$ & \multicolumn{2}{|c|}{$\begin{array}{c}\text { 3 months } \\
\text { post -program }\end{array}$} \\
\cline { 2 - 7 } & $\mathbf{r}$ & $\mathbf{P}$ & $\mathbf{r}$ & $\mathbf{P}$ & $\mathbf{r}$ & $\mathbf{P}$ \\
\hline $\begin{array}{l}\text { Transformational leadership from } \\
\text { nursing clinical educators } \\
\text { viewpoint }\end{array}$ & $0.720^{*}$ & $<0.001^{*}$ & $0.309^{*}$ & $0.005^{*}$ & $0.543^{*}$ & $<0.001^{*}$ \\
\hline
\end{tabular}

r: Pearson coefficient

*: Statistically significant at $\mathrm{p} \leq 0.05$

Table (8): Correlation between nursing clinical educators ' knowledge about sense of responsibility and sense of responsibility from their viewpoint at pre, immediate post, and 3 months post program $(n=80)$

\begin{tabular}{||l|c|c|c|c|c|c||}
\hline \multirow{2}{*}{} & \multicolumn{6}{|c|}{ Knowledge about sense of responsibility } \\
\cline { 2 - 7 } & \multicolumn{2}{|c|}{ Pre-program } & $\begin{array}{c}\text { Immediate post } \\
\text {-program }\end{array}$ & \multicolumn{2}{|c|}{$\begin{array}{c}\text { 3 months } \\
\text { post -program }\end{array}$} \\
\cline { 2 - 7 } & $\mathbf{r}$ & $\mathbf{P}$ & $\mathbf{r}$ & $\mathbf{P}$ & $\mathbf{r}$ & $\mathbf{P}$ \\
\hline $\begin{array}{l}\text { Sense of responsibility from } \\
\text { nursing clinical educators' } \\
\text { viewpoint }\end{array}$ & $0.627^{*}$ & $<0.001^{*}$ & $0.529^{*}$ & $<0.001^{*}$ & $0.550^{*}$ & $<0.001^{*}$ \\
\hline
\end{tabular}

r: Pearson coefficient

*: Statistically significant at $\mathrm{P} \leq 0.05$ 
Table (9): Correlation between transformational leadership from nursing clinical educators' viewpoint and sense of responsibility from their viewpoint at pre, immediate post, and 3 months post program $(n=80)$

\begin{tabular}{|l|c|c|c|c|c|c||}
\hline \multirow{2}{*}{} & \multicolumn{5}{|c||}{$\begin{array}{r}\text { Transformational leadership from nursing clinical } \\
\text { educators' viewpoint }\end{array}$} \\
\cline { 2 - 7 } & \multicolumn{2}{|c|}{ Pre-program } & $\begin{array}{c}\text { Immediate post } \\
\text {-program }\end{array}$ & \multicolumn{2}{|c||}{$\begin{array}{c}\text { 3 months } \\
\text { post -program }\end{array}$} \\
\cline { 2 - 7 } & $\mathbf{r}$ & $\mathbf{P}$ & $\mathbf{r}$ & $\mathbf{P}$ & $\mathbf{r}$ & $\mathbf{P}$ \\
\hline $\begin{array}{l}\text { Sense of responsibility from } \\
\text { nursing clinical educators' } \\
\text { viewpoint }\end{array}$ & $0.832^{*}$ & $<0.001^{*}$ & $0.757^{*}$ & $<0.001^{*}$ & $0.703^{*}$ & $<0.001^{*}$ \\
\hline
\end{tabular}

r: Pearson coefficient

*: Statistically significant at $\mathrm{p} \leq 0.05$ 


\section{Discussion}

Nursing clinical educators' transformational leadership is the most effective leadership approach. It focuses on the NCEs/students relationship with a sense of responsibility for the improvement of both NCEs and students. Transformational nursing clinical educators with high sense of responsibility engage student in communication; enhance students' learning, innovation, creativity, and ethical behavior; enrich student's abilities and skills; as well as create a learning atmosphere that promotes improved student success ${ }^{(14,23)}$.

Transformational NCEs provide a strong base for professional advancement, career achievement, job autonomy, and job motivation. Hence, the TNCEs with high sense of responsibility become important characteristic to put into consideration $^{(12,14)}$. Therefore, this study aimed to determine the effect of implementing transformational leadership educational program on sense of responsibility of nursing clinical educators at Faculty of Nursing.

\section{I) Pre-educational program}

\section{A) Nursing clinical educators' transformational leadership}

Pre-program assessment of nursing clinical educators' level of transformational leadership knowledge revealed that the majority of them had a low level (Table
2). Also, majority of nursing clinical educators rated themselves as low level of transformational leadership at preeducational program (Table 4). This may be due to inadequate NCEs' understanding about basic concepts, dimensions, and benefits of transformational leadership.

Also, most of those NCEs were novice and didn't attend previous training program about transformational leadership (Table 1). This means that majority of NCEs serve as insufficient role model for their students, poorly inspire students to think critically, and rarely treated their students as an unique individual. So, this result indicates that those NCEs are in need to sufficient knowledge and training about transformational leadership.

Along with the present finding, Mallek and El-Hosany (2020) ${ }^{(33)}$ who revealed that all clinical instructors' level of knowledge in pre intervention was poor. Also, Cuciac et al., (2015) ${ }^{(34)}$ found that math teachers as having less transformational leadership style. Tessema (2015) ${ }^{(35)}$ indicated that the majority of the North Gondar Zone public preparatory school teachers' level of overall transformational leadership was low.

On the other hand, Elsayed and Shokier (2019) (36) found that the majority of clinical nursing educators rated themselves as high level of transformational leadership. Edrees (2018) ${ }^{(18)}$ found high 
percent of nursing students rated their clinical educator in moderate and high level transformational leadership. And Bryant (2015) (22) found that undergraduate nursing instructors possessed and demonstrated transformational leadership at high level.

In this respect, according to DeDeyn (2021) (37), the teachers should be enthusiastic, establish a vision for their class, challenge students, and use rewards strategically which are characteristics of transformational teacher.

B) Nursing clinical educators' sense of responsibility

Pre-program assessment of nursing educators' knowledge about sense of responsibility revealed that the majority of them had a low level (Table 3). Also, majority of nursing clinical educators felt themselves as low level of sense of responsibility at pre-educational program (Table 5). This may be due to decline in NCEs' understanding about basic concepts, dimensions, factors affecting, components, and importance of sense of responsibility. Also, this may be due to inadequate opportunities to practice their responsibilities, especially in novice NCEs, due to corona virus crisis and its consequences of work restrictions.

In this respect, Yough et al. (2020) (38) stated that sense of responsibility is important for acquiring the needed skills and knowledge to work effectively with students, student academic progress, and non-learning outcomes such as student well-being outside the classroom. The teachers' sense of responsibility, according to Eren (2014) (39), notified existing curricular and educational efforts to increase teaching and teacher quality. This achieved by drawing attention to sense of responsibility which means the degree to which an individual feels personally responsible for the results of the work she / he does. Also, Lauermann and Karabenick (2013) (15) stated that teachers' sense of personal responsibility is highly significant for student learning and achievement.

\section{II)Immediate post educational program}

Results of present study at immediate post program implementation revealed that there was significant improvement in nursing clinical educators' knowledge about transformational leadership and sense of responsibility (Tables 2 \& 3 ). Also, there was significant improvement in transformational leadership and their sense of responsibility from nursing clinical educators' viewpoint (Tables 4 \& 5).

This improvement in present study may result from utilizing new teaching approaches that facilitate the learning process. Also, this shows that the present educational program had a positive effect to improve of NCEs' knowledge. 
Furthermore, this knowledge that acquired through educational program assist NCEs to improve their transformational leadership and sense of responsibility. They had understood their basic role. This understanding permits them to execute their duties effectively and efficiently.

Educational program helps those NCEs to be at good level of transformational leadership and sense of responsibility; have the capacity in the profession; be autonomous; have control over their work; and be self-directing. Additionally, program provides NCEs with a chance to develop awareness, review their practices, and alter their practices in an atmosphere that may be more comfortable than real life situations.

Along with the present study, Singh (2020) (40) demonstrated statistically significant increase of transformational leadership dimensions after educational sessions about the transformational leadership. Mallek and El-Hosany (2020) $^{(33)}$ found that majority of clinical instructors' level of knowledge in post intervention were excellent. Abdel Rahiem et al. (2020) ${ }^{(41)}$ found that all clinical instructors had high skill level at immediate post of program. AbdElrhaman and Abd-Allah (2018) (42) found that a highly statistically significant improvement in knowledge scores and skills regarding transformational leadership immediate post program than pre-program scores. Aly (2018) (31) revealed that post program implementation, revealed that there was significant improvement in nursing demonstrators' knowledge and practice.

On the same line, El said (2018) (30) revealed that post program, the majority of nursing demonstrators showed satisfied level of performance positively correlated to their high mean score of knowledge about clinical teaching. El Zeneny et al. (2017) (43) found statistical significant differences and marked improvement in participants total knowledge as the highest percentage of them immediately and after 3months post program compared to preprogram.

Also, El said (2013) ${ }^{(30)}$ supported study result and stressed that the importance of educational program for instructors to enable them to provide an opportunity for student nurses to improve their essential knowledge and skills.

\section{III) Three months after educational program}

Results of present study three months after educational program implementation, revealed that three months after program implementation, there was significant improvement in nursing clinical educators' knowledge about transformational leadership and sense of responsibility more than pre-educational program 
implementation; but slightly decreased than immediate post educational program implementation (Tables 2 \& 3). Also, there was significant improvement transformational leadership and their sense of responsibility from nursing clinical educators' viewpoint; more than preeducational program implementation; but slightly decreased than immediate post educational program implementation

\section{(Tables 4\& 5).}

This may be due to time factor, the point that some theoretical knowledge that not utilized in regular practice is expected to be decreased, diminished or even lost with passage of time especially in corona virus crisis and its work restrictions. This indicated the importance of continuous follow up and guidance after program implementation. Giving periodical enforcement or educational program for NCEs is very important as recommended by Aly (2018) ${ }^{(31)}$.

In the same line, Mallek and El-Hosany (2020) (33) found that the clinical instructors knowledge increased at follow up program compared to pre-program. Abdel Rahiem et al. (2020) ${ }^{(41)}$ found that the skill levels of all clinical instructors were high after three months of program. Also, there was highly statistically significant increase in skills levels after three months of program.
Also, El said (2018) ${ }^{(30)}$ found that there was a decline in participants' knowledge after three months post program and reported that the improvement in knowledge can be affected by capacity of knowledge acquisition, accumulation of learned knowledge of life, the rate of memorization, and the refreshing information using various approaches of active learning during implementation of program.

In accordance with the present study, Burnham (2018) ${ }^{(44)}$ found that follow-up interviews with participants gave greater insight into their use of the transformative leadership qualities observed by the researcher in the classroom. AbdElrhaman and Abd-Allah (2018) (42) found that a highly statistically significant improvement in head nurses knowledge scores and skills regarding transformational leadership three months follow up the program than pre-program scores. El Zeneny et al. (2017) ${ }^{(43)}$ found statistically significant differences and marked improvement in participants total knowledge as the highest percentage of them after 3months post program compared to preprogram.

IV) The

correlation

between

transformational leadership and their sense of responsibility

The present study displayed a statistically significant positive correlation between 
transformational leadership and their sense of responsibility from nursing clinical educators' viewpoint. This means that transformational leadership increase NCEs' sense of responsibility. This may be because transformational leadership enhance their responsibility for clinical teaching, students' motivation, positive relationships, and students' achievement.

Along with the present finding, Andrian et al. (2018) (45) showed that transformational leadership has a positive and significant effect on the teachers performance of their responsibilities. Mammen and Pushpanadham (2018) ${ }^{(46)}$ found that there was a significant correlation between transformational leadership and teachers' accountability. Khany and Ghoreishi (2014) ${ }^{(14)}$ found that transformational leadership style was a positive predictor of teachers' sense of responsibility. It was concluded that higher transformational leadership style contributes to higher sense of responsibility.

From the definition of sense of responsibility as a sense of obligation or commitment, Noraazian and Khalip (2016) ${ }^{(47)}$ transformational leadership had positive and significant relationship with teacher's commitment. This means that transformational leadership predicts organizational commitment. Feizi et al. (2014) (48) found that there was a significant positive correlation between transformational leadership and organizational commitment of teachers.

In the same line, Ibrahim et al. (2014) ${ }^{(49 y)}$ revealed that there was a significant relationship between transformational leadership and teachers' commitment to teaching profession. In contrary, Mallek and El-Hosany (2020) ${ }^{(33)}$ found that there was no correlation between clinical instructors' performance and their knowledge in pre, post, and follow-up program.

Finally, the present study stresses that the implementation of the educational program was success as a mean to improve NCEs' knowledge and practice. That program assisted those NCEs to have better transformational leadership skills and sense of responsibility. Through transformational leadership skills and sense of responsibility. NCEs are able to perform their responsibilities efficiently and effectively. So the designed educational program was important for NCEs to promote their knowledge and practice of transformational leadership and sense of responsibility.

\section{Conclusion}

Nursing clinical educators at Tanta University Faculty of Nursing showed low knowledge level of transformational leadership and sense of responsibility Also, they rated themselves as low level of 
transformational leadership and sense of responsibility. Nursing clinical educator develop transformational leadership and sense of responsibility after careful implementation of program.

\section{Recommendations}

Based on the findings of the current study, the following recommendations can be suggested:

\section{- Faculty administrator}

1. Conduct ongoing educational programs and training for the all nursing clinical educators about role of transformational leadership as a valuable strategy for upgrading their sense of responsibility

2. Teach transformational leadership and sense of responsibility is a basic part of faculty training program

3. Create a supportive environment for transformational leadership practice.

4. Set up an orientation program for preparation of novice nursing clinical educators about their responsibilities

5. Place posters about nursing clinical educators' responsibilities at various places at the nursing faculty

6. Assess nursing clinical educators' learning needs continuously and monitor their performance.

\section{-Nursing educators}

7. Guide and support continuously for nursing clinical educators to practice transformational leadership.
8. Provide greater autonomy for nursing clinical educators to enhance their transformational leadership and their sense of responsibility.

9. Encourage self-learning among nursing clinical educators.

10. Motivate nursing clinical educators to participate in various faculty educational programs and training about the transformational leadership and the sense of responsibility.

\section{-Nursing clinical educators}

11. Use transformational leadership with students in clinical training

12. Seek to know their job responsibilities.

13. Effectively apply their responsibilities.

14. Participate in various faculty educational programs and training about the transformational leadership and the sense of responsibility.

\section{Recommendations for further research}

The current study findings consider a basis for further research such as:

Identify factors affecting nursing clinical educators' transformational leadership.

Study the relation between nursing clinical educators' transformational leadership and their quality of work life.

Investigate the relation between 
nursing clinical educators' transformational leadership and their job satisfaction

Expand the implementation of educational program about transformational leadership for nursing clinical educators' in various universities.

Explain the relation of nursing clinical educators' sense of responsibility and their performance.

\section{References}

1. Longren T. Define Nurse Educator and How to Prepare to Become aNurse Educator. International Journal of Nursing Education. 2011; 8(1): 22-27.

2. Whittaker B, Newman B. Preceptor Manual. Bachelor of Midwifery School of Health Charles Darwin University. 2015. Available at:http://www.cdu. edu.au/sites/default/files/facultiesplace ment/docs/preceptor-manual.pdf

3. Toelke L. The Clinical Nurse Instructor: Best Practices in Orienting Newly Hired Clinical Faculty. Published M.D Thesis. Wallington State University, College of Nursing. 2012.

4. Billing $\mathrm{D}$, Halstead J. Teaching in Nursing. $5^{\text {th }}$ ed. EL Seveir. USA. 2016: $1-5$

5. Adelman-Mullally $\mathrm{T}$, Mulder $\mathrm{C}$, Spalding M., Hagler D., Gaberson K., Hanner M., et. The clinical nurse educator as leader. Journal of Nurse Education in Practice. 2013; 13(1): 2934.

6. Antonakis J, Day D. The Nature of Leadership. $3^{\text {rd }}$ ed. London. SAGE Publications, Inc. 2018: 5-6.

7. Wilson A. From Professional Practice to Practical Leader: Teacher Leadership in Professional Learning Communities. International Journal of Teacher Leadership. 2016; 7(2): 45-62.

8. Harrison J. Instructor Transformational Leadership and Student Outcomes. Journal of Emerging Leadership Journeys. 2011 ;4(1): 82- 136

9. Murdock R. The Significance and Integration of Transformational Instructor Leadership Behaviors to A University Performance Management System: A Sequential Mixed Methods Study. Published Doctoral Thesis. Faculty of the Graduate School of Creighton University. 2019.

10. Balwant P. Transformational Instructor-Leadership in Higher Education Teaching: A MetaAnalytic Review and Research Agenda. Journal of Leadership Studies. (2016); 9(4): 20-42.

11. Daniels R. Goodboy A. Transformational Leadership in the Ghanaian University Classrooms. Intercultural Communication Studies. 2014;13 (2): 90-109 
12. Jovanovic D, Ivanovic M. Benefits of Transformational Leadership in the Context of Education. 2016. Published by European Proceedings of Social and Behavioural Sciences (EpSBS). Available at: https://www.europeanproceedings.co m/files/data/article/45/1218/article_4 5_1218_pdf_100.pdf

13. Harrison J. The Effects of Instructor Transformational Leadership and Verbal Immediacy on Learner Autonomy and Creativity in Online Contexts. Published Doctor Thesis. Regent University. 2013. Available from: ProQuestDissertationsand Theses database

14. Khany R, Ghoreishi M. On The Relationship Between Teachers' Sense of Responsibility and Transformational Leadership Style. Journal of Procedia - Social and Behavioral Sciences. 2014; 136 (9): $302-307$.

15. Lauermann F, Karabenick S. The meaning and measure of teachers' sense of responsibility for educational outcomes. Journal of Teaching and Teacher Education. 2013; 30(2): 13-26.

16. Lauermann F. Teacher Responsibility from The Teacher's Perspective. International Journal of
Educational Research. 2014; 65(7): 75-89

17. Matteucci M, Guglielmi D, Lauermann F. Teachers' Sense of Responsibility For Educational Outcomes and its Associations with Teachers' Instructional Approaches and Professional Wellbeing. Journal of Social Psychology of Education. 2017; 20(2): 275-298

18. Edrees D. Relation between Levels of Clinical Educators' Transformational Leadership and Nursing Students' Academic Self Efficacy. Unpublished MD Thesis. Tanta University. 2018.

19. Kellish A. Leadership Styles of Clinical Coordinators and Clinical Instructors in Physical Therapy Clinical Education. Published Doctoral Thesis. Seton Hall University Dissertations and Theses (ETDs). 2014. Available at: http://scholarship.shu.edu/dissertatio ns/2113

20. Fisher A. Transformational Leadership in Nursing: A Concept Analysis. Journal of Advanced Nursing. 2016; 72 (11): 2644-2653.

21. Chmer A. Investigating Trans formational Leadership Practices in Private Schools from Teachers' Perspectives Schools from Teachers' 
Perspectives. United Arab Emirates

University. 2020. Master Thesis.

Foundations of Education.

22. Bryant M. Leadership Practices Among Undergraduate Nursing Instructors. Published Doctoral Thesis. University of Southern Mississippi. 2015.

23. Slavich M, Zimbardo G. Transformational Teaching:

Theoretical Underpinnings, Basic Principles, and Core Methods. Educational Psychology Review. 2012; 24(4): 569-608.

24. Peters J. Transformational Teachership: How Principles of Transformational Leadership Foster Student Outcomes. Doctor Thesis. Colorado State University. 2014.

25. Tsai K. Development of The Teacher Leadership Style Scale. Journal of Social Behavior and Personality. 2017; 45(3): 477-490.

26. Lisette Hornstra L, Mansfield C, Veen I, Peetsma T, Volman M. Motivational teacher strategies: The role of beliefs and contextual factors. Learning Environ Res. 2015; 18(1): 363-392.

27. $\mathrm{Li}$ Y. Teacher-Student Relationships, Student Engagement, and Academic Achievement for Non-Latino and Latino Youth.
Journal of Adolescent Res Rev. 2018; 3(1):375-424.

28. Williams A. Teachers' Beliefs about Fostering Teacher-Student Relationships and the Correlation to Academic Gains. Published Doctoral Thesis. Liberty University. 2017.

29. McDonald E. The Nurse Educator's Guide to Assessing Learning Outcomes. 4th ed. Boston: Jones \& Bartlett Co. 2017:12-13.

30. El said Z. Clinical Teaching Competences of Nursing Demonstrators at Faculty of Nursing Post Intervention program. Published Doctoral Thesis. Faculty of Nursing, Tanta University. 2018.

31. Aly A. Efficacy of program about Students' Performance Assessment Feedback on Knowledge and Practices of Nursing Demonstrators. Published Doctoral Thesis. Faculty of Nursing, Tanta University. 2018.

32. Gerstman B. Basic Biostatistics, Statistics for Public Health Practice. 2nd ed. Canada. Jones and Bartlet Publisher, Inc. 2015: 200-300.

33. Mallek S, El-Hosany W. Training Program for Improving Clinical Teaching Knowledge as a Competence of Clinical Instructors. American Journal of Nursing Research. 2020; 8(3): 379-391. 
34. Cuciac, L., Tepordei, A., Labar A., and Cătălin, C., The Influence of Teachers' Perceived Leadership Styles and Students' Learning Approaches on Academic Achievement. Journal of Education and Development, Research and Practice, 2015; 2(1):9-21.

35. Tessema G. Assessing the relationships between transformational leadership and employees' engagement in North Gondar Zone Public preparatory school teachers, Ethiopia. Journal lof Economics, Business and Management. 2015; 2 (10B):10761085.

36. Elsayed A, Shokier E. Transformational Leadership and Work Engagement Among Clinical Nursing Educators. International Journal of Novel Research in Healthcare and Nursing. 2019; 6( 2): 1711-1722.

37. DeDeyn R. Teacher Leadership and Student Outcomes in a US University Intensive English Program. 2021; 24(4)

38. Yough M, Gilmetdinova A, Finney E. Teaching the English Language Learner at the Elementary School: Sense of Responsibility in an IllDefined Role. Journal of Language,
Identity \& Education, 2020. DOI: 10.1080/15348458.2020.1791707

39. Eren, A. Uncovering The Links Between Prospective Teachers' Personal Responsibility, Academic Optimism, Hope, and Emotions about Teaching: a Mediation Analysis. Journal of Social Psychology of Education. 2014; 17(1), 73-104.

40. Singh A. Implementation and Evaluation of a Transformational Leadership Education Session For Nurse Leaders and Nurse Educators. Journal of Doctoral Nursing Practice. 2020;13(2):125-133.

41. Abdel Rahiem S, Abo Habieb E, ElShaer A. Impact of Clinical Supervision Program on Nursing Students' Achievement. IOSR Journal of Nursing and Health Science. . 2020; 9(1): 13-26.

42. Abd-Elrhaman E, Abd-Allah N. Transformational Leadership Educational Program For Head Nurses and its Effect on Nurses' Job Performance. American Journal of Nursing Science 2018; 7(4): 127-136

43. El Zeneny S. Effect of Clinical Supervision Training Program for Nurse Managers on Quality of Nursing Care in ICU, Master Thesis. Cairo University, Faculty of nursing. 2017. 
44. Burnham S. Transformational Leadership in The Special Education Classroom and Its Impact on Student Connectedness. Published Doctoral Thesis. University of New England 2018. From All Theses and Dissertations.

45. Andrian S, Kesumawati N, Kristiawan M. The influence of The transformational leadership and work motivation on teachers performance. International Journal of Scientific \& Technology Research. 2018; 7(7):19-29.

46. Mammen J, Pushpanadham K. Accountability of Teachers: Does It Invigorate Transformational Leadership in Schools? Journal Pendidikan Malaysia. 2018; 43(2): 29-35.

47. Noraazian A, Khalip G. The Impact of Transformational Leadership And Teacher Commitment in Malaysian Public Schools. International Journal of Academic Research in Business and Social Sciences. 2016; 6(11):388-397.

48. Feizi M, Ebrahimi E, Beheshti N. Investigating the relationship between transformational leadership and organizational commitment of high school teachers in Germi. International Journal of Organizational Leadership. 2014; 3(1): 17-30.
49. Ibrahim S, Ghavifekr S, Ling S, Siraj S, Azeez I. Can Transformational Leadership Influence on Teachers' Commitment Towards Organization, Teaching Profession, and Students Learning? A Quantitative Analysis. Asia Pacific Education Review. 2014; 15(2):177-190. 